\title{
THE CHEMICAL PROPERTIES COMPARATIVE OF YEAST HYDROLYSATE ENZYMATIC (YHE) FROM YEAST THAT FERMENTED IN RICE FLOUR VARIATION
}

\author{
R. Agustini ${ }^{1}$, I. G. M. Sanjaya ${ }^{1}$ and A. Widodo ${ }^{2}$ \\ ${ }^{1}$ Department of Chemistry, Universitas Negeri Surabaya, Surabaya-60231, Surabaya, Indonesia \\ ${ }^{2}$ Chemistry Department, University of Brawijaya, Malang-65145, Malang, Indonesia \\ * E-mail: rudianaagustini@unesa.ac.id
}

\begin{abstract}
YHE is a yeast extract from enzymatic hydrolysis. Yeast as a raw material for YHE can be fermented in white, red and black rice, which have different chemical compositions. This study aims to describe the chemical composition of YHE from fermented yeast in rice flour variation, hereinafter referred to as YHE-white rice (Y-WR), YHE-red rice (Y-RR), and YHE-black rice (Y-BR). The chemical composition measured was: $\mathrm{Cr}^{3+}, \mathrm{Cr}^{6+}, \% \mathrm{protein}^{6}$ amino ratio $(\mathrm{N}-\alpha) /(\mathrm{NT})$ content, $\%$ crude fiber, and $\%$ starch. The results showed that YHE from yeast grown in black rice flour had the highest $\mathrm{Cr}^{3+}, \mathrm{Cr}^{6+}$, protein, amino ratio $(\mathrm{N}-\alpha) /(\mathrm{NT})$ compared to YHE from yeast that fermented in white and red rice flour, and it had the lowest content crude fiber and starch.
\end{abstract}

Keywords: Chemical Composition, Rice, Yeast, Yeast Hydrolysate Enzymatic, Extranx Yeast.

(c) RASĀYAN. All rights reserved

\section{INTRODUCTION}

YHE is the result of enzymatic hydrolysis of yeast or better known as yeast extract. This material is known to be rich in compounds that are useful in the body's metabolism. Yeast has a variety of types, one of which is Saccharomyces cerevisiae, a monocellular fungus. Yeast can be grown in various media that are rich in carbohydrates. This Yeast extract has been used as a nutritional supplement for many years. Foodstuffs that are rich in carbohydrates, one of which is rice. There are so many types of rice, for example white, red, and black rice, which are known to have different chemical compositions.

Yeast extract has so many benefits, there are, as a medium to grow a microbial, often used as for fertilizers and pesticides in agriculture field ${ }^{1}$, yeast extract can also be used as a flavor enhancer for the food industry and household needs ${ }^{2}$, nutritional deficiency supplements, For many years, peptone and various amino acids containing yeast extract have been used as nutritional components in the culture media.

Some of the chemical components contained in yeast and YHE are very important for metabolism and growth, including $\mathrm{Cr}^{3+}, \mathrm{Cr}^{6+}, \%$ protein, total $\alpha$-amino nitrogen $(\mathrm{N}-\alpha), \%$ crude fiber, and $\%$ starch. Chromium can be obtained from Foodstuffs and is available in very small quantities (1-2 micrograms or less). Chromium which is important in foodstuffs is chromium 3 (indicating oxidation level). Trivalent chromium $\left(\mathrm{Cr}^{3+)}\right.$ is the most stable form of chromium ${ }^{3}$, safest, and is one of the least toxic. ${ }^{4}$ Chromium works to facilitate the entry of glucose in the body's cells. Insulin hormone helps glucose to enter the cells of the body by forming a complex with chromium. Hyperglycemia can be formed if the body's cell doesn't react to insulin. The presence of $\mathrm{Cr}^{6+}$ in foodstuffs is also important because it is toxic. The benefits of protein in food will be used by cells to form enzymes (proteins that catalyze biochemical reactions), contractile proteins (actin, myosin, tubulin, dynein), regulatory proteins (hormones), transport proteins (hemoglobin, myoglobin, albumin), integral proteins regulates the entry and exit of ions into and out of cells, cell signaling receptors, structural proteins (keratin, fibroin, collagen, elastin), defense proteins (antibodies, fibrinogen). Amino acids in foodstuffs play an important role in building up proteins, while this compound also acts as an energy source. Amino acids are the building blocks of proteins and

Rasayan J. Chem., 12(4), 1839-1849(2019)

http://dx.doi.org/10.31788/RJC.2019.1245314

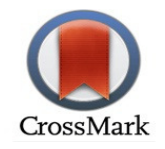


are intermediates in carbohydrate metabolism (glycolysis). The crude fiber in food (dietary fiber) is useful for helping digestion, sterol metabolism, fermentation in the large intestine, nutrients absorption, and stool weight. ${ }^{5}$ Whereas starch is needed as an energy source. ${ }^{6,7}$

\section{Preparation of Bromelain Enzymes}

\section{EXPERIMENTAL}

Preparation of bromelain enzyme carried out includes extraction and isolation of bromelain from pineapple. Pineapple diced, then mashed filtered and taken the filtrate. The filtrate was centrifuged at $1500 \mathrm{rpm}$ at $4^{\circ} \mathrm{C}$ for 15 minutes to remove cell biomass, then the supernatant obtained was precipitated by adding 35\% ammonium sulfate (Sigma, p.a) and stirring for 45 minutes. The next stage was carried out centrifugation speed of $4000 \mathrm{rpm}$, and the precipitate obtained was bromelain. To eliminate small molecules, dialysis is carried out.

\section{Yeast Production}

The initial stage of making YHE is yeast production and preparing the media for its growth. The yeast used in this study is commercial bakery yeast. The growth media used were white, red and black rice flour. Flour preparation is done by grinding white, red and black rice. The flour obtained was sieved using a 100 mesh sieve slip. Each of rice flour is added to distilled water in a ratio of 5:1 (w/v). The mixture is heated to form a gel (gelatinization process). The gel was cooled, then enzymatically hydrolyzed using $\alpha$ amylase and glucoamylase for 6 hours. The hydrolyzate produced was used for yeast growth media, and then fermented for 96 hours. Yeast is obtained by centrifuge at $6,000 \mathrm{rpm}$ for 15 minutes and the residue obtained is yeast, which is ready for further processing into YHE.

\section{YHE Production}

The yeast produced in the previous stage is lysed and hydrolyzed using the bromelain enzyme. The procedure in more detail is $20 \%$ (w/w) of yeast biomass placed into Erlenmeyer and suspended at 1.200 $\mathrm{ml}$ of distillate water, set to an initial $\mathrm{pH}$ of 6.5 (arrangements can be made using $10 \mathrm{~N} \mathrm{NaOH}$ ). The next step is to incubate by using a water bath at a temperature of $95^{\circ} \mathrm{C}$ for 15 minutes, then it cool slowly, and $0.6 \%$ bromelain is added. The mixture is slowly stirred using a magnetic stirrer at a speed of $200 \mathrm{rpm}$. Hydrolysis carried out at a temperature of $40^{\circ} \mathrm{C}$ for 12 hours, will produce hydrolyzate. Hydrolyzate is clarified, centrifuged and a deposit called YHE will be obtained. The chemical content of YHE is ready to be tested including $\%$ protein, $\%$ crude fiber, $\%$ starch, $\% \mathrm{Cr}^{3+}$, and $\% \mathrm{Cr}^{6+}$.

\section{Determination of Chromium Content, $\mathrm{Cr}^{3+}$ and $\mathrm{Cr}^{6+}$}

The cyclic voltammetry method is used to determine the content of chromium content such as $\mathrm{Cr}^{3+}$ and $\mathrm{Cr}^{6+}$ from YHE. ${ }^{8}$ The first step taken in determining the content of chromium is the preparation of a standard solution. In this study using a standard solution of $\mathrm{K}_{2} \mathrm{Cr}_{2} \mathrm{O}_{7}$ and $\mathrm{CrCl}_{3} \cdot 6 \mathrm{H}_{2} \mathrm{O}$ (sigma, p.a), the concentration variation of 5,10,20,40 and $80 \mathrm{ppm}$. Measurements were made using Silica-Carbon Electrode with a scanning rate of $50 \mathrm{mV} / \mathrm{sec}$. Measurement of a standard solution using a voltammeter produces a voltammogram, which is then processed using the Origin-Pro program and a standard curve is made between concentration and current so that a linear regression equation is obtained $\mathrm{y}=\mathrm{a}+\mathrm{bx}$. Furthermore, measurements of each sample solution were carried out, the results of which were entered into the equation and the $\mathrm{Cr}^{3+}$ and $\mathrm{Cr}^{6+}$ contents of the sample tested would be known.

\section{Determination of Protein Content}

Determination of protein content using the Kjeldahl method ${ }^{9}$, as much as 5 grams of YHE-black, white and red rice was put into the Kjeldahl flask, 1.4 grams of the catalyst was added and boiling stones, $5 \mathrm{ml}$ of concentrated $\mathrm{H}_{2} \mathrm{SO}_{4}$. The sample is destructed until the color becomes green and then left to cool. The sample was added $60 \mathrm{ml}$ of distilled water, shaken, and put into the Erlenmeyer $300 \mathrm{ml}$. In this distillation stage, the sample solution was diluted by adding $40 \% \mathrm{NaOH}$ and distilled. If all $\mathrm{N}$ has reacted with sulfuric acid in the flask, the distillation process is stopped. The next stage is the titration process using $\mathrm{NaOH}$. The titration process stops if there is a change in color. Besides the sample, there is a blank 
solution that is made from distilled water. The nitrogen content of the titration results is used to calculate the percentage of TKN (Total Kjeldahl Nitrogen) with the following formula:

\begin{tabular}{ll}
\multicolumn{1}{c}{$\% \mathrm{TKN}$} & $\frac{(\mathrm{ml} \text { sample- ml blank solution }) \times 14.007 \times \mathrm{N}}{\mathrm{mg} . \text { sample }} \times 100 \%$ \\
Where: & \\
ml sample & $=$ sample titrant volume $(\mathrm{ml})$ \\
$\mathrm{ml}$ blank solution & $=$ blanks titrant volume $(\mathrm{ml})$ \\
$\mathrm{N}$ & $=$ titrant normality \\
$\mathrm{mg}$. Sample & $=$ weight of sample $(\mathrm{mg})$
\end{tabular}

\section{Determination of The Content of $\alpha$-Amino Nitrogen ( $\mathbf{N}-\alpha)$}

Amino acids were determined using HPLC (Waten, Model 244) which was equipped with a fluorescence detector (420-AC model, excitation $=334 \mathrm{~nm}$, and emission $=425 \mathrm{~mm}$ ). The working step is to hydrolyze the sample, weigh the sample 10-15 mg, add $25 \mathrm{ml}$ of $6 \mathrm{~N} \mathrm{HCl}$, then put it in the hydrolysis tube. The liquid in the tube is frozen with liquid nitrogen or solid $\mathrm{CO}_{2}$ (dry ice), then the tube is vacuumed, and after vacuum, closed tightly. Next, the tube is heated in the oven at a temperature of $110^{\circ} \mathrm{C}$ for 6 hours, then cooled. After that $\mathrm{HCI}$ is removed by evaporation under infrared light. The residue containing amino acids was dissolved in $0.01 \mathrm{M} \mathrm{HCI}$, and to dissolve tyrosine a buffer phosphate solution $\mathrm{pH} 7.0$ was used. The solution is filtered using a Millipore filter measuring $0.45 \mathrm{~g}$. Next, the samples were injected on the HPLC instrument with the motion phase column conditions: Amino Acid Analysis column-TM. The cation exchange resin $\left(\mathrm{SO}^{3-} \mathrm{Na}^{+}\right)$: A citrate buffer $\mathrm{pH}=3.0, \mathrm{~B}$ Borate buffer $\mathrm{pH}=9.8$. The injection volume of the detector is $10 \mu \mathrm{L}{ }^{10}$

\section{Determination of Crude Fiber Content}

Crude fiber content is determined using the method AOAC. ${ }^{9}$ Oil-paper weighed (A gram). YHE made from red rice flour are weighed as much as 1 gram on oil paper (B gram), put into a beaker glass specifically for crude fiber analysis. Added $0.3 \mathrm{~N} \mathrm{H}_{2} \mathrm{SO}_{4}$ (sigma) as much as $50 \mathrm{~mL}$ then simmer for 30 minutes. $\mathrm{NaOH} 1.5 \mathrm{~N}$ was added and boiled again for 25 minutes. EDTA was added as much as 0.5 grams and boiled again for 5 minutes. Filtered the suspension with a filtration dish and the residue left in the glass beaker was washed with hot distilled water. The solution of $0.3 \mathrm{~N} \mathrm{HCl}$ (sigma) has added as much as $50 \mathrm{~mL}$, and left for 1 minute then sucked with a vacuum oven $80^{\circ} \mathrm{C}$. Added with $10 \mathrm{~mL}$ of hot distilled water ( 5 times). Aceton has added as much as $40 \mathrm{~mL}$, left for 1 minute and filtered. The samples to be heated at $105^{\circ} \mathrm{C}$ for 1.5 hours. Entered in a desiccator for 1 hour and weighed ( $\mathrm{C}$ gram). Enter into the furnace at a temperature of $550^{\circ} \mathrm{C}-600^{\circ} \mathrm{C}$ for 2 hours. Re-entered the desiccator for 1 hour and weighed (D gram).

\section{Determination of Starch Content}

Starch is measured colorimetrically by using iodine reagent. The substrate in the form of starch solution with variations of the concentration of $10 \mathrm{mg} / \mathrm{mL}$ and $20 \mathrm{mg} / \mathrm{mL}$ each of $5 \mathrm{~mL}$ was dissolved in a $5 \mathrm{~mL}$ phosphate buffer. Then $1 \mathrm{~mL}$ of the supra $\alpha$-amylase enzyme was added to the $7 \mathrm{~mL}$ mixture. The solution was then incubated in an incubator at $37^{\circ} \mathrm{C}$ for 30 minutes. The reaction was stopped by adding 1 $\mathrm{mL}$ of $1 \mathrm{~N} \mathrm{HCl}$. The remaining a starch concentration in the solution is measured indirectly by measuring the absorbance value of the solution mixed with $1 \mathrm{~mL}$ iodine solution. Iodine solution was prepared by dissolving 5 grams of $\mathrm{KI}$ and $500 \mathrm{mg} \mathrm{I}$ in $100 \mathrm{~mL}$ of water to be diluted as much as 100 times. The absorbance value was measured using a UV-Vis spectrophotometer at a wavelength of $620 \mathrm{~nm}$. The readable concentration is then determined from the absorbance value on the calibration curve. ${ }^{11,12}$

\section{RESULTS AND DISCUSSION}

YHE is an enzymatically hydrolyzed yeast extract, which uses the enzyme bromelain from pineapple. Yeast is fermented in white, red and black rice media. The chemical composition of Yeast Hydrolysate 
Enzymatic (YHE) from yeast fermented in a variety of rice flour consists of \% protein, \% fiber, \% starch, $\% \mathrm{Cr}^{3+}, \% \mathrm{Cr}^{6+}$, and $\%$ amino acids. This study also determines the protein content of rice flour as a medium of fermentation and yeast as raw material for YHE which is used as a comparison. The following tables 1 to 5 describe the content of protein, crude fiber, starch, $\mathrm{Cr}^{3+}$, and $\mathrm{Cr}^{6+}$ of YHE. The protein of YHE is determined using the Kjeldahl method. YHE protein content data are shown in Table-1.

Table-1: Protein Content of YHE

\begin{tabular}{l|c|c|c|c}
\hline Material Type & $\begin{array}{c}\text { \% Protein } \\
\text { Content }\end{array}$ & $\begin{array}{c}\text { Difference Protein } \\
\text { Between Flour and } \\
\text { Yeast in \% }\end{array}$ & $\begin{array}{c}\text { Difference Protein } \\
\text { Between Flour and } \\
\text { YHE in \% }\end{array}$ & $\begin{array}{c}\text { Difference Protein } \\
\text { Between Yeast and } \\
\text { YHE in \% }\end{array}$ \\
\hline Flour-WR & 7.45 & - & - & - \\
\hline Flour-RR & 9.06 & - & - & - \\
\hline Flour-BR & 10.60 & - & - & - \\
\hline Yeast-WR & 40.00 & 32.55 & - & - \\
\hline Yeast-RR & 38.66 & 29.6 & - & - \\
\hline Yeast-BR & 40.19 & 29.59 & 31 & 1.55 \\
\hline Y-WR & 38.45 & - & 29.42 & 0.96 \\
\hline Y-RR & 38.48 & - & 28.63 & \\
\hline Y-BR & 39.23 & - & & \\
\hline Wh & & & & - \\
\hline
\end{tabular}

Where:

Flour-WR, Flour-RR, and Flour-BR respectively are white, red and black rice flour

Yeast-WR, Yeast-RR, and Yeast-BR are white, red, and black rice yeast, respectively.

Y-WR, Y-RR, and Y-BR are enzymatic yeast hydrolysate from white, red and black rice flour

The results of the analysis of protein content showed that yeast-BR had the highest protein content of all materials tested, which amounted to 40.19\%. The highest increase in protein content during the fermentation process was achieved by flour-WR media which was equal to $32.55 \%$, while the increase in flour-RR media and flour-BR was almost the same as the increase, which was $29.6 \%$ and $29.59 \%$ respectively. One possible cause of this increase is the activity of yeast in fermenting glucose in the media to be metabolized into cell proteins. Meanwhile during the enzymatic hydrolysis process to produce YHE there was a decrease in $\%$ protein such as a reduction in Y-WR of $1.55 \%$, Y-RR of $1.71 \%$, and Y-BR of $0.96 \%$. This is one of the possible reasons that many proteins escaped during the centrifuge stage. Based on the data analysis conducted it can be concluded that the highest protein content is yeast-BR products of 40.19\%. The highest protein content for YHE was found in Y-BR, which was 39.23\%. Proteins are the most common macromolecules found in cells of living things and are 50 percent or more of the dry weight of cells. The role of proteins in metabolism is as a biocatalyst, growth factor, maintaining $\mathrm{pH}$ stability, maintaining cell fluid balance, helping to form antibodies to fight infection, cell transportation, energy sources, membrane transportation. ${ }^{13}$ To maintain fluid balance in the body, proteins regulate it, the proteins are Albumin and globulin by attracting and retaining water. ${ }^{14,15}$ Protein plays an important role as a regulator for concentrations of acids and bases in your blood and other bodily fluids. ${ }^{16}$ The benefits of protein are so large and the recommended protein intake for a person is around one gram (or less) per kilogram of body weight. Data from the measurement of crude fiber content are presented in Table- 2 . Fiber level measurements were carried out using the AOAC method ${ }^{9}$.

The results of the analysis of fiber content or crude fiber show that yeast-RR has the highest fiber content, which is equal to $14.88 \%$. Y-RR also has the highest fiber content compared to Y-WR and Y-BR, but YHE has lower content than yeast. At the time of the enzymatic hydrolysis process added bromelain enzymes to hydrolyzes proteins. Enzymes are proteins so the addition of bromelain enzymes lowers other components, including crude fiber. The data in Table- 2 also shows a decrease in the crude fiber content of all YHE. The decrease of $\%$ flour-WR fiber to yeast-WR, flour-RR to yeast-RR, and flour-BR to yeastBR were $5.58 \%, 3.68 \%$, and $3.57 \%$ respectively. The biggest difference is yeast-BR. Whereas the decrease in $\%$ crude fiber from flour-WR to Y-WR, flour-RR to Y-RR, and flour-BR to Y-BR were $7.26 \%, 8.11 \%$, and $5.71 \%$ respectively. 
RASĀYAN J. Chem.

Vol. 12 | No. 4 |1839 - 1849| October - December | 2019

Table-2: YHE Crude Fiber Content

\begin{tabular}{l|c|c|c|c}
\hline $\begin{array}{c}\text { Material } \\
\text { Type }\end{array}$ & $\begin{array}{c}\text { \% Crude } \\
\text { Fiber }\end{array}$ & $\begin{array}{c}\text { Difference Crude } \\
\text { Fiber Between Flour } \\
\text { and Yeast in \% }\end{array}$ & $\begin{array}{c}\text { Difference Crude Fiber } \\
\text { Between Flour and YHE } \\
\text { in \% }\end{array}$ & $\begin{array}{c}\text { Difference Crude } \\
\text { Fiber Between Yeast } \\
\text { Dan YHE in \% }\end{array}$ \\
\hline Flour-WR & 1.31 & - & - & - \\
\hline Flour-RR & 3.09 & - & - & - \\
\hline Flour-BR & 2.43 & - & - & - \\
\hline Yeast-WR & 13.15 & 11.84 & - & - \\
\hline Yeast-RR & 14.88 & 11.79 & - & - \\
\hline Yeast-BR & 11.71 & 9.28 & - & 7.26 \\
\hline Y-WR & 5.89 & - & 4.58 & 8.11 \\
\hline Y-RR & 6.77 & - & 3.68 & 5.71 \\
\hline Y-BR & 6 & - & 3.57 & \\
\hline
\end{tabular}

Crude fiber, including carbohydrates, these compounds cannot be digested by gastrointestinal enzymes, but are useful and are known to reduce the risk of heart disease and diabetes millitus. ${ }^{17}$ Fiber can help slow down the absorption of sugar, control body weight, facilitate bowel movements, reduce constipation and hemorrhoids, reduce colon cancer. Some studies explain that diabetics who consume a lot of fiber need less insulin than those who don't. Table-3 shows the starch content in the test ingredients determined by colorimetry.

\begin{tabular}{c|c|c|c|c}
\hline Sample Name & \% Starch & $\begin{array}{c}\text { Difference Starch } \\
\text { Between Rice Dan } \\
\text { Yeast in \% }\end{array}$ & $\begin{array}{c}\text { Difference Starch } \\
\text { Between Rice Dan } \\
\text { YHE in \% }\end{array}$ & $\begin{array}{c}\text { Difference Starch } \\
\text { Between Yeast Dan YHE } \\
\text { in \% }\end{array}$ \\
\hline Flour-WR & 33.952 & - & - & - \\
\hline Flour-RR & 17.960 & - & - & - \\
\hline Flour-BR & 13.265 & - & - & - \\
\hline Yeast-WR & 9.467 & 24.485 & - & - \\
\hline Yeast-RR & 6.643 & 11.317 & - & - \\
\hline Yeast-BR & 5.424 & 7.841 & 25.920 & 6.169 \\
\hline Y-WR & 8.031 & - & 12.811 & 5.230 \\
\hline Y-RR & 5.149 & - & 10.654 & \\
\hline Y-BR & 2.611 & - & & \\
\hline
\end{tabular}

Based on the data in Table-3, it can be seen that WR has the highest starch content compared to RR or $\mathrm{BR}$, which is $33.952 \%$ and $\mathrm{BR}$ is the smallest starch content which is $13.265 \%$. Likewise, for yeast-WR, it also has higher starch content compared to yeast-RR and yeast-BR which is $9,677 \%$ and yeast-BR has the lowest starch content when compared to yeast-WR and yeast-BR, which is 5,424\%. Likewise, for YWR it also has higher starch content compared to Y-RR and Y-BR which is $8.031 \%$ and Y-BR has the lowest starch content compared to Y-WR and Y-RR which is $2.611 \%$. Starch content of Y-WR is the lowest of fluorine-WR and yeast-WR which is equal to $8.031 \%$, then Y-RR also has the lowest starch content when compared to flour-RR or yeast-RR which is $5.149 \%$, so too Y-BR content is the lowest when compared to flour-BR and yeast-WR which is $2.611 \%$. The data in Table 3 shows a decrease in starch content during the process of making YHE. A decrease in starch content from flour-WR to WRyeast was $24.485 \%$. A decrease in starch content from WR flour to WR-yeast is highest compared to RR flour to RR-yeast and BR flour to BR-yeast. Whereas the decrease in starch content from BR-flour to BRyeast showed the smallest results. This shows the ability of enzymes to degrade the largest flour-WR and degrade the smallest flour-BR. The data in Table-3 also shows the highest reduction in Y-WR starch among the treatments given, which is $16.453 \%$. Y-BR is the smallest, which is $5.230 \%$. It can be explained that the ability to bind starch by Y-WR is the smallest and the ability to bind starch by Y-BR is 
the highest among the treatments given. Y-BR has the smallest decrease in fiber content compared to other $\mathrm{Y}$ so that a lot of starch is contained in Y-BR when the manufacturing process is mainly when centrifuging. Starch is a carbohydrate, a polymer consisting of a large number of glucose units that join a glycosidic bond. The main function of starch is a source of energy for the body. The results of the $\mathrm{Cr}^{3+}$ measurements of each ingredient are shown in Table- 4 below.

Table-4: $\mathrm{Cr}^{3+}$ Content of YHE

\begin{tabular}{c|c|c|c|c}
\hline Materials & $\mathrm{Cr}^{3+}$ Content (\%) & $\begin{array}{c}\text { Difference } \mathrm{Cr}^{3+} \\
\text { Between Flour } \\
\text { and Yeast in \% }\end{array}$ & $\begin{array}{c}\text { Difference } \mathrm{Cr}^{3+} \\
\text { Between Flour } \\
\text { and YHE in \% }\end{array}$ & $\begin{array}{c}\text { Difference } \mathrm{Cr}^{3+} \\
\text { Between Yeast } \\
\text { and YHE in \% }\end{array}$ \\
\hline Flour-WR & 0.002 & - & - & - \\
\hline Flour-RR & 0.0019 & - & - & - \\
\hline Flour-BR & 0.002 & - & - & - \\
\hline Yeast-WR & 0.0101 & 0.0081 & - & - \\
\hline Yeast-RR & 0.0103 & 0.0084 & - & 69 \\
\hline Yeast-BR & 0.0112 & 0.0092 & - & 66 \\
\hline Y-WR & 0.0032 & - & 0.0012 & 72 \\
\hline Y-RR & 0.0037 & - & 0.0018 & \\
\hline Y-BR & 0.004 & - & 0.002 &
\end{tabular}

The data in Table-4 shows that the content of $\mathrm{Cr}^{3+}$ in yeast-WR, yeast-RR and yeast-BR is different from flour-WR, flour-RR, and flour-BR, which are $0.0081 \%, 0.0018 \%$ and $0.0092 \%$ respectively. This difference is probably due to the addition of baker's yeast during the fermentation process. The results showed that yeast bakery contained $\mathrm{Cr}^{3+}$. Likewise, the chromium content of Y-WR, Y-RR, and Y-BR is also different from flour-WR, flour-RR, and flour-BR respectively $0.0012,0.0018$ and $0.0020 \% .{ }^{1}$ The highest $\mathrm{Cr}^{3+}$ content is in yeast-BR, while YHE which has the highest $\mathrm{Cr}^{3+}$ is Y-BR. Chromium which has a valence of $3\left(\mathrm{Cr}^{3+}\right)$ is an important trace mineral that the body needs to metabolize carbohydrates and fats. ${ }^{18}$ This mineral is stable and not toxic. The role of these minerals is: (1) maintaining the balance of blood sugar levels and increasing the work efficiency of insulin. Chromium is often referred to as "Glucose Tolerance Factor" (a factor controlling blood sugar levels) needed for processing glucose into energy; (2) helps to lose weight by burning fat into energy; (3) reduce cholesterol and triglycerides so that they can maintain heart health; (4) increase muscle mass so that it can form the ideal muscle; and (5) help synthesize cholesterol, fat, and protein and improve muscle tissue. Glucose transport into cells is stimulated by chromium, where chromium will form a complex with insulin.

Measurement of $\mathrm{Cr}^{6+}$ content in the material was also carried out because in an acidic condition $\mathrm{Cr}^{6+}$ can be changed to $\mathrm{Cr}^{3+}$. The $\mathrm{Cr}^{6+}$ measurement results from each material are shown in Table-5.

The data in Table- 5 shows that the $\mathrm{Cr}^{6+}$ content is almost the same in yeast-WR, yeast-RR, and yeast BR, which is $0.0039,0.0040$, and $0.0044 \%$. Likewise, what happened to Y-WR, Y-RR, and Y-BR from flourWR, flour-RR, and flour-BR respectively amounted to $0.0006,0.0008$, and $0,001 \%$. The results of this study also showed that after the enzymatic yeast hydrolysis process became YHE there was a decrease in $\mathrm{Cr}^{6+}$ content similar to that of Y-WR, Y-RR, and Y-BR which was $0.0034,0.0032$, and $0.0034 \% . \mathrm{Cr}^{6+}$ is known to be relatively toxic. This ion is unstable and will change to $\mathrm{Cr}^{3+}$ in an acidic environment. Important components in food ingredients, one of them, are amino acids. Table- 6 shows the results of measurements of $\alpha$-amino nitrogen $(\mathrm{N}-\alpha)$ of YHE.

The data in Table- 6 shows that the content of $\mathrm{N}-\alpha$ for each amino acid in YHE is similar, but because the NT content of each amino acid is not the same, the $\mathrm{N}-\alpha / \mathrm{NT}$ value is different. Y-BR has the highest value $(\mathrm{N}-\alpha) /(\mathrm{NT})$ when compared to Y-WR and Y-RR, which is $21,671 \%$. This indicates that the largest amino acid content is obtained from YHE-BH. Amino acids are compounds resulting from protein degradation. The amino acids are required for many vital functions of the organism ${ }^{19}$, like protein monomers including enzymes, as components of vitamins, hormones, and nucleic acids), and important metal binders needed in enzymatic reactions (cofactors). This compound play numerous role as intermediates in the biosynthesis of other metabolisms, including purine nucleotide, pyrimidine nucleotide, polyamine, 
RASĀYAN J. Chem.

Vol. 12 | No. 4 |1839 - 1849| October - December | 2019

glutathione, creatine phosphate, neurotransmitter, aromatic compound and pigments, hormones, porphyrins, and other amino acids. ${ }^{20}$

Tabel-5: $\mathrm{Cr}^{6+}$ Content of the Material.

\begin{tabular}{c|c|c|c|c}
\hline Material & $\begin{array}{c}\mathrm{Cr}^{6+} \text { Content } \\
(\%)\end{array}$ & $\begin{array}{c}\text { Difference in \% } \\
\mathrm{Cr}^{6+} \text { (Flour and } \\
\text { Yeast })\end{array}$ & $\begin{array}{c}\text { Difference in \% } \\
\mathrm{Cr}^{6+} \text { (Flour and } \\
\text { YHE) }\end{array}$ & $\begin{array}{c}\text { Difference in \% } \\
\mathrm{Cr}^{6+} \text { (Yeast and } \\
\text { YHE) }\end{array}$ \\
\hline Flour-WR & 0.0009 & - & - & - \\
\hline Flour-RR & 0.0009 & - & - & - \\
\hline Flour-BR & 0.0009 & - & - & - \\
\hline Yeast-WR & 0.0048 & 0.0039 & - & - \\
\hline Yeast-RR & 0.0049 & 0.0040 & - & 0.0034 \\
\hline Yeast-BR & 0.0053 & 0.0044 & - & 0.0032 \\
\hline Y-WR & 0.0015 & - & 0.0006 & 0.0034 \\
\hline Y-RR & 0.0017 & - & 0.0008 & \\
\hline Y-BR & 0.0019 & & 0.0010 & \\
\hline
\end{tabular}

Table-6: Content of $\alpha$-Amino Nitrogen ( $\mathrm{N}-\alpha$ ) Ingredients (in \% Dry Weight)

\begin{tabular}{c|c|c|c}
\hline Component & Y-WR $(\%)$ & Y-RR $(\%)$ & Y-BR $(\%)$ \\
\hline Isoleucine & 0.39 & 0.34 & 0.39 \\
\hline Leucine & 0.66 & 0.62 & 0.71 \\
\hline Methione & 0.14 & 0.13 & 0.12 \\
\hline Phenylanine & 0.37 & 0.31 & 0.45 \\
\hline Threonine & 0.43 & 0.37 & 0.44 \\
\hline Valine & 0.48 & 0.43 & 0.50 \\
\hline Alanine & 0.36 & 0.34 & 0.38 \\
\hline Agrinine & 0.35 & 0.32 & 0.46 \\
\hline Cystine & 0.05 & 0.05 & 0.06 \\
\hline Glutamic & 1.42 & 1.48 & 1.55 \\
\hline Glycine & 0.35 & 0.30 & 0.38 \\
\hline Histidine & 0.15 & 0.13 & 0.19 \\
\hline Proline & 0.31 & 0.30 & 0.35 \\
\hline Serine & 0.43 & 0.39 & 0.46 \\
\hline Tyrosine & 0.25 & 0.26 & 0.35 \\
\hline Lisin & 0.57 & 0.40 & 0.46 \\
\hline Aspartat & 0.86 & 0.75 & 0.83 \\
\hline Total & 7.58 & 6.93 & 8.09 \\
\hline (N- $\alpha$ )/(NT) & 16.1105 & 16.614 & 21.671
\end{tabular}

Where:

$\mathrm{N}-\alpha: \alpha$-amino nitrogen

NT : N total measurement results with the Kjeldahl method.

Some research indicate an important role for amino acids in immune responses by regulating: (1) the activation of T lymphocytes, B lymphocytes, natural killer cells and macrophages; (2) cellular redox state, gene expression and lymphocyte proliferation; and (3) the production of antibodies, cytokines and other cytotoxic substances $^{13}$. Amino acids making up proteins are known to have 20 kinds, each of which has a different function, namely: isoleucine, leucine, methionine, phenylalanine, threonine, valine, alanine, arginine, cysteine, glutamic, glycine, histidine, proline, serine, tyrosine, lysine, aspartate. This amino acid is divided into 2 groups, namely essential and non-essential amino acids. Essential amino acids are amino acids that cannot be synthesized in the body, meaning they must be obtained from the outside. isoleucine, leucine, methionine, phenylalanine, threonine, valine, arginine, histidine, lysine, tryptophan. Nonessential amino acids are amino acids that can be synthesized in the body. The non-essential amino acids include alanine, cysteine, glutamine, glycine, proline, serine, tyrosine, aspartate, asparagine, and glutamate. 
Isoleucine plays a role in maintaining the stability of protein structure. Hemoglobin synthesis which is a major component of red blood cells is strongly influenced by isoleucine. Leucine, an essential amino acid. Leucine is a hydrophobic amino acid. Leusin functions in increasing the synthesis of growth hormone. Valine is known to role play in metabolism as protein constituents. Arginine is an essential amino acid that the body needs to make seminal fluid (semen), and strengthen the immune system. As a supplement, it is usually used with other amino acids, such as lysine. Lowers low pressure, promotes blood circulation. Antiatherogenic, reduce fat levels (cholesterol), dilate blood vessels (increase peripheral blood flow), strengthen the heart muscle, stimulate secretion of growth hormone (Human Growth Hormone), inhibit oxidative stress/tissue damage, enhance the immune system, heal wounds. Histidine is needed during growth to repair body tissue and convert excess glucose into glycogen which is processed in the liver. Histidine is converted into histamine. This compound plays a role in stimulating gastric acid secretion. The production of red blood cells and white blood cells is also influenced by histidine.

The benefits of lysine: (1) help calcium absorption, which indirectly prevents bone loss or osteoporosis; (2) helps build muscle and collagen; (3) plays a role in fatty acid metabolism; (4) supporting the production of other proteins, including hormones, antibodies, and enzymes that are very important to make the body's performance more optimal; (5) stimulates the production of digestive enzymes so that it can stimulate appetite. Methionine has an important role in biochemical reactions. This compound serves as an inhibitor for the enzyme elastase which is triggered by compounds in cigarette smoke, where the compound is one of the causes of emphysema. Methionine can give its methyl group in a reaction to form S-Adenosyl-L-Methionine (SAM). Another essential amino acid is phenylalanine, it's hydrophobic. Phenylalanine is nearly always found buried within a protein. Phenylalanine is almost always found in proteins. The $\pi$ electrons from the phenyl ring can overlap with $\pi$ electrons from other aromatics in the folded protein thereby increasing the stability of the structure. Threonine is another hydroxyl-containing amino acid. In pregnant women, this compound is needed for bone formation. Bone and tooth strength is needed for this compound. Threonine will work together with calcium, vitamin $\mathrm{K}$ and other minerals to maintain the density and function of bones and teeth. Threonine can boost the immune system by helping the body to produce stronger antibodies. Antibodies will help the body ward off infections from bacteria, fungi or the source of the virus. This amino acid helps the body produce collagen which can make the skin elastic. Threonine is very important for maintaining liver health, reducing fat in the liver, and maintaining liver activity to keep it functioning properly. Liver health problems often cause fatal health conditions such as liver cirrhosis and diseases due to impaired liver function. Threonine is also important for maintaining mental health. This method helps the body when mentally or psychologically disturbed. Stress and excessive pressure cause health problems because it will make the physical condition weaker and more susceptible to disease. Threonine is also important in maintaining a healthy nervous system. High threonine levels in the body can help the body heal wounds or injuries. The mechanism of threonine in the body will increase the body's immunity. This can improve tissue, nerve function. and metabolism for the better. The alanine is an intermediate in the Krebs cycle. This compound can undergo transamination with $\alpha$-ketoglutarate to produce pyruvate.

Tryptophan functions in the synthesis of biogenic amines, hormone precursors, serotonin, a compound that plays a role in regulating the nervous system. The cysteine is an amino acid that contains sulfur. This compound is responsible for stabilizing an extracellular protein. Two cysteine molecules can form dimers through sulfide bonds and produce one cystine molecule. Essential amino acids themselves are a type of amino acid that is needed by the body but cannot be produced by the body. This causes us to need foods that contain essential amino acids to meet the needs of essential amino acids in our bodies. Some of the amino acids included in these essential amino acids are valine, histidine, tryptophan, isoleucine, lysine, leucine, methionine, threonine and phenylalanine.

Tyrosine is a precursor of thyroid hormones, melanin, and catecholamines. The thyroid is hormones that stimulated a number metabolism process, through activation of the particular gene. Other benefits of tyrosine are: (1) contributing to protein synthesis; (2) help stimulate the nervous system to work perfectly so that the mood can be controlled stably so that we are not easily stressed or depressed about something or someone; (3) prevent hypothyroidism; (4) together with essential phenylalanine amino, this tyrosine 
RASĀYAN J. Chem.

Vol. 12 | No. 4 |1839 - 1849| October - December | 2019

will be able to produce norepinephrine, dopamine, and epinephrine, all three of which are neurotransmitter compounds; (5) plays a role in the formation of melanin.

Glycine is a glucogenic nature like serine and alanine, meaning that amino acids can be metabolized into glucose and subsequently used as an energy source. This amino acid plays a role in glycogen metabolism, the formation of glutathione, purine nucleotides, as well as porphyrins (hemoglobin rings). Hemoglobin plays a role in oxygen transport. Another benefit of glycine is to stimulate creatine production, a compound that is useful for building muscle mass.

An amino acid that has two side groups and is bound to one another is proline. The main benefit of proline is that it forms collagen in the body. Proline is useful for maintaining skin tightness so that it prevents it from wrinkling (sagging) which is usually caused by sunlight. Collagen is a smooth and flexible tissue that attaches to the bone like glue. Collagen is the main structural protein found throughout the human body. This compound also maintains skin firmness, cartilage and joint health to reduce friction between bones. Proline helps maintain health and also speeds up the process of healing cartilage and also joints that are experiencing interference. In conjunction with other amino acids, lysine, proline is a precursor for hydroxyproline and hydroxylation. Hydroxyproline is used by the body to make collagen, tendons, ligaments, and also the heart muscle. Collagen in our body consists of $15 \%$ proline. These conditions make proline have benefits for treatment such as arthritis, sprains in soft tissue, and also chronic back pain. Proline plays an important role in preventing atherosclerosis or hardening of the arterial wall, a condition that often causes other cardiovascular disorders. Proline is one of the important components for forming collagen in the body. By increasing the intake of ingredients that contain proline, the amount of collagen in the body and also the skin layer will increase so that various skin disorders such as premature aging caused by sun exposure and free radicals can be prevented. Proline intake is known to be very important especially for someone who is in a period of soft tissue trauma such as injury, during healing of wounds, severe burns, or postoperative injuries. Proline is an important compound to accelerate the process of wound healing through tissue repair by increasing collagen fragments to stimulate healing faster. Someone who is in a healing period usually has to get a higher amount of proline intake than healthy people in general.

Serine is an amino acid that makes up proteins that function to enhance the immune system, which plays a role in antibody and immunoglobulin substances. Serine is in a protein whose function supports the formation of the brain and also myelin sheaths, although it is indeed rare. The absence of serine, the effectiveness of the myelin sheath will decrease when the message is delivered. serine can be converted into tryptophan, an amino acid that is very useful as the main ingredient in the production of serotonin in the brain.

Phenylalanine together with taurine and tryptophan are compounds that function as transmitters or messengers (neurotransmitters) in the brain's nervous system. This amino acid is responsible for controlling body weight, because of its effect in regulating the secretion of the thyroid gland and suppressing appetite (control of appetite). Phenylalanine deficiency can result in red eyes (bloodshot eyes), cataracts, and behavioral changes (psychotic and schizophrenic). Phenylalanine is a precursor of a tyrosine that has a function as a precursor of pigments.

Alanine plays a role in the glucose-alanine cycle, a process of transporting ammonia from the muscles to the liver. Aspartic acid have functions as generator of neurotransmission in the brain and nerve muscles, protecting the liver by helping to remove excess ammonia from the body, protect the liver by removing ammonia out of the body, helping cell function in the formation of RNA or DNA, playing a role in the formation of immunoglobulins and antibodies and reducing ammonia in the blood after exercise. Glutamate is one of several amino acids serving as precursors to compounds that function in the transmission of nerves impulse, namely $\gamma$-butyric acid, which is the main fuel of brain cells with glucose, reduces alcohol dependence and stabilizes mental health. Asparagine is important in the nervous system which is to maintain balance and in the conversion of amino acids. This amino acid plays a role in the urea cycle too. Glutamine plays a role in the transport of toxic ammonia from peripheral tissues to the liver.

The following Table-7 shows the results of the recapitulation of the chemical rice flour composition (fermented media), yeast (the raw material of yeast extract) and yeast extract. 
RASĀYAN J. Chem.

Vol. 12 | No. 4 |1839 - 1849| October - December | 2019

Table-7: Results of Recapitulation of YHE Chemical Composition in Rice Flour Variations

\begin{tabular}{c|c|c|c|c|c|c|c}
\hline Samples & $\begin{array}{c}\text { Water } \\
\text { Content } \\
(\%)\end{array}$ & $\mathrm{Cr}^{3+}(\%)$ & $\mathrm{Cr}^{6+}(\%)$ & $\begin{array}{c}\% \\
\text { Protein }\end{array}$ & $\begin{array}{c}\text { Total of } \alpha-\text { Amino } \\
\text { Nitrogen }(\mathrm{N}-\alpha)(\%)\end{array}$ & $\begin{array}{c}\% \text { Crude } \\
\text { Fiber }\end{array}$ & $\%$ Starch \\
\hline Flour-WR & 89.00 & 0.0020 & 0.0048 & 7.45 & - & 3.09 & 33.952 \\
\hline Flour-RR & 89.00 & 0.0019 & 0.0049 & 9.06 & - & 2.43 & 17.960 \\
\hline Flour-BR & 89.00 & 0.0020 & 0.0053 & 10.60 & - & 1.31 & 13.265 \\
\hline Yeast-WR & 77.00 & 0.0101 & 0.0048 & 40.00 & - & 6.77 & 9.467 \\
\hline Yeast-RR & 74.06 & 0.0103 & 0.0049 & 38.00 & - & 5.89 & 6.643 \\
\hline Yeast-BR & 72.21 & 0.0113 & 0.0053 & 40.19 & - & 6.00 & 5.424 \\
\hline Y-WR & 52.95 & 0.0032 & 0.0015 & 38.45 & 7.58 & 14.88 & 8.031 \\
\hline Y-RR & 58.29 & 0.0037 & 0.0017 & 38.48 & 6.93 & 13.15 & 5.149 \\
\hline Y-BR & 62.67 & 0.0040 & 0.0019 & 39.23 & 8.09 & 11.71 & 2.611 \\
\hline Where & & & & & & &
\end{tabular}

Where :

- $\quad$ : No measurements are taken

The data in Table-7 shows that- (1) the highest $\mathrm{Cr}^{3+}$ level was a yeast-BR product of $0,0113 \%$ and YHE which contained the highest $\mathrm{Cr}^{3+}$ was Y-BR; (2) The highest $\mathrm{Cr}^{6+}$ level is the yeast-BR product of 0,0053 $\%$. Yeast-BR has the highest protein content of all treatment, which is $40.19 \%$. Y-RR has the highest fiber content among the given yeast treatments, which is $14.88 \%$. Y-RR also has the highest fiber content among the given Y (YHE) treatments. Flour-WR has higher starch content compared to Flour-RR or Flour-BR, which is $33.952 \%$. Y-WR also has a higher starch content compared to Y-RR and Y-BR which is $8.031 \%$. Y-BR has the largest amino acid $(\mathrm{N}-\alpha) /(\mathrm{N})$ content compared to $\mathrm{Y}-\mathrm{WR}$ and $\mathrm{Y}-\mathrm{RR}$, which is $8.09 \%$.

\section{CONCLUSION}

The results of the research showed that YHE from yeast grown in black rice flour had the highest $\mathrm{Cr}^{3+}$, $\mathrm{Cr}^{6+}$, protein, amino ratio $(\mathrm{N}-\alpha) /(\mathrm{NT})$ compared to YHE from yeast that fermented in white and red rice flour, and it had the lowest content crude fiber and starch.

\section{ACKNOWLEDGMENT}

We thank you to the Director of DRPM for giving us the opportunity to conduct this research. Thank you also to the Rector and Chair of the Surabaya State University Research and Service Institute who have been willing to provide financial assistance through the University's Leading Basic Research.

\section{REFERENCES}

1. R. Agustini, and M. Adiprahara, Advanced Science Letters, 23(12), 12020(2017), DOI: 10.1166/asl.2017.10565

2. T. Godfrey and J. Reichet, Industrial Enzymology, The Application of Enzyme in Industry, Stockton Press, Great Britain (1986)

3. Ikuko Kato, Joseph H. Vogelman, Vladimir Dilman, Jerzy Karkoszka, Krystyna Frenkel, Nancy P. Durr, Norman Orentreich, Paolo Toniolo, European Journal of Epidemiology,14(6), 621(1998).

4. R. Anderson, Journal of the American College of Nutrition, 17(6), 548(1998), DOI: 10.1080/07315724.1998.10718802

5. A. Caprita, R. Caprita, V. O. G. Simulescu, Journal of Agrolimentary Processes and Technologues, 16(4), 406(2010).

6. J. M. Berg, Tymeczko, G. J. Gatto, and L. Stryer, Biochemistry, 8th Edition, Freeman Macmillan (2015)

7. A. L. Lehninger, L. N. David, and M. C. Michael,The Principle of Biochemistry, $7^{\text {th }}$ Edition. W.H. Freeman (2016)

8. E. Yulianto, Unesa Journal of Chemistry, 3(3), 60(2014). 
9. AOAC, Official Methods Of Analysis Of Association Of Oficial Analytical Chemists, Washington D.C (2000)

10. S. Rediatning and H. N. Kartini, Proceeding ITB, 2(1/2), 41(1987)

11. M. Yaldagard, S. A.Mortazavi, F. Tabatabaie, World Applied Sciences Journal, 3, 91(2008).

12. Z. Xiao, R. Storms, A. Tsang, Analytical Biochemistry, 351,146(2006), DOI: 10.1016/j.ab.2006.01.036

13. P. Li, Y. L. Yin, D. Li, S. W. Kim, G. Wu, Br J Nutr. 98, 2, 237(2007), DOI: 10.1017/S000711450769936X

14. J. T. Busher, The History, Physical, and Laboratory: Serum Albumin and Globulin Examinations. 3rd Edition Boston, Butterworths (1990).

15. J. J. Hankins, Infus. Nurs., 29(5),260(2006), DOI:10.1097/00129804-200609000-00004

16. L. L. Hamm, N. Nakhoul, and Kathleen S. Hering-Smith, Clin. J. Am. Soc.Nephrol., 10, 12, 2232(2015), DOI:10.2215/CJN.07400715

17. C. B. Breneman and L. Tucker, Br. J. Nutr., 110(2),375(2013), DOI: 10.1017/S0007114512004953

18. B. E. Wilson, A. Gondy, Diabetes Research and Clinical Practice, 28(3),179(1995), DOI: 10.1016/0168-8227(95)01097-W

19. D. Voet, and J. Voet, Biochemistry, $4^{\text {th }}$ Edition, English: John Wiley and Sons Ltd. (2011).

20. C. Mathew, K. E. van Holde, D. R. Appling, and S. J. Anthony-Cahill, Biochemistr, $4^{\text {th }}$ Edition. Publisher Pearson, (2012).

[RJC-5314/2019] 